\title{
Mortality of Common Eider, Somateria mollissima (Linnaeus, 1758), and other Water Birds during two Inshore Oiling Events in Southeastern Newfoundland, 2005 and 2006
}

\author{
Gregory J. Robertson ${ }^{1,3}$, Scott G. Gilliland ${ }^{1}$, Pierre C. Ryan ${ }^{1}$, Johanne Dussureault ${ }^{1}$, Kyran \\ POWER $^{2}$, and BRUCE C. TURNER ${ }^{1}$
}

\author{
${ }^{1}$ Canadian Wildlife Service, 6 Bruce Street, Mount Pearl, Newfoundland and Labrador A1N 4T3 Canada \\ ${ }^{2}$ P.O. Box 21, St. Mary's Bay, Newfoundland and Labrador A0B 1E0 Canada \\ ${ }^{3}$ Corresponding author: greg.robertson@ec.gc.ca
}

\begin{abstract}
Robertson, Gregory J., Scott G. Gilliland, Pierre C. Ryan, Johanne Dussureault, Kyran Power, and Bruce C. Turner. 2014. Mortality of Common Eider, Somateria mollissima (Linnaeus, 1758), and other water birds during two inshore oiling events in southeastern Newfoundland, 2005 and 2006. Canadian Field-Naturalist 128(3): 235-242.
\end{abstract}

\begin{abstract}
Although the waters off Newfoundland harbour millions of wintering marine birds, chronic marine oil pollution has been repeatedly reported. Unusually high numbers (hundreds) of oiled birds were noted following two events in March 2005 and April 2006 in southeastern Newfoundland. Common Eiders (Somateria mollissima [Linnaeus, 1758]) were the main victims in the first event, with at least 1400 affected, based on retrieval of carcasses and aerial surveys. The April 2006 event affected 19 species; Common Eiders were again the most numerous with a minimum of 337 birds oiled. Among the Common Eiders affected in both events, most were the northern type, including the borealis (C. L. Brehm, 1824) subspecies and presumed intergrades between borealis and dresseri Sharpe, 1871. Coupled with the legal harvest, these oiling events may have had an effect on the wintering Common Eider population. Alcids, other sea ducks, loons and gulls were also oiled, but in low numbers $(<100)$; thus, their populations were not likely affected by these events.
\end{abstract}

Key Words: Oil pollution; Common Eider; Somateria mollissima; water birds; Avalon Peninsula; Newfoundland

\section{Introduction}

The cold, productive waters off Newfoundland and Labrador, Canada, are home to large populations of breeding and wintering marine birds (Lock et al. 1994). However, chronic oiling problems have been documented in the coastal waters of Newfoundland (Wiese and Ryan 2003), likely because of the large numbers of ships that transit these waters. Although murres (Uria spp.) and Dovekies (Alle alle [Linnaeus, 1758]) are most severely affected by oiling, other species, including sea ducks, are also found (Wiese and Ryan 2003). Among the coastal wintering species, the Common Eider (Somateria mollissima [Linnaeus, 1758]) is the most numerous and also an important game bird in Newfoundland (Wendt and Silieff 1986; Gilliland and Robertson 2009). Unlike pelagic seabirds, which tend to be widely distributed, Common Eiders may form dense flocks, and a single oiling event can affect a large component of the population. Oil spills affecting Common Eiders have occurred in Atlantic Canadian waters in the past (Brown et al. 1973).

Two significant events involving hundreds of oiled coastal birds occurred from late February to early April 2005 and April 2006 in southeastern Newfoundland (a third event in November 2004 involving mostly pelagic species is described elsewhere [Robertson et al. 2006]). In this paper, we present information from a variety of surveys conducted to assess the geographic scope of these incidents and estimate the number of eiders and other water birds at risk and actually oiled from these spills. To help understand potential effects on populations, we present information on oiled carcasses to assess the population structure and affinities of birds killed. Finally, we evaluate the potential effect of these two oiling events on eiders and other water birds wintering in Newfoundland.

\section{Study Area and Methods \\ March 2005 incident}

On Saturday, 26 February 2005, wildlife officials and pollution prevention officers received reports that oiled eiders were being taken during the legal hunt. Further reports were received on Monday, 28 February 2005 , the final day of the open hunting season for sea ducks in Newfoundland. On 1 March, an experienced observer (S.G.G.) used a Canadian Coast Guard helicopter (BO-105, Bölkow, Stuttgart, Germany) to survey the east coast of the Avalon Peninsula from Cape St. Francis to Cape Race (Figure 1) and count the number of eiders at risk in the area and visibly oiled eiders. The survey began and ended at Cape St. Francis, beginning at 1030 and ending at 1345 . Survey conditions were excellent: light easterly winds, clear sky, and a temperature of $-5^{\circ} \mathrm{C}$. The flight track and all observations were recorded using United States Fish and Wildlife Service Global Positioning System Voice Software.

During the initial flight, from north to south at $500 \mathrm{~m}$ above sea level, the size and location of all large flocks of eiders and Black-legged Kittiwakes (Rissa tridactyla [Linnaeus, 1758]) were recorded. On the return flight, 


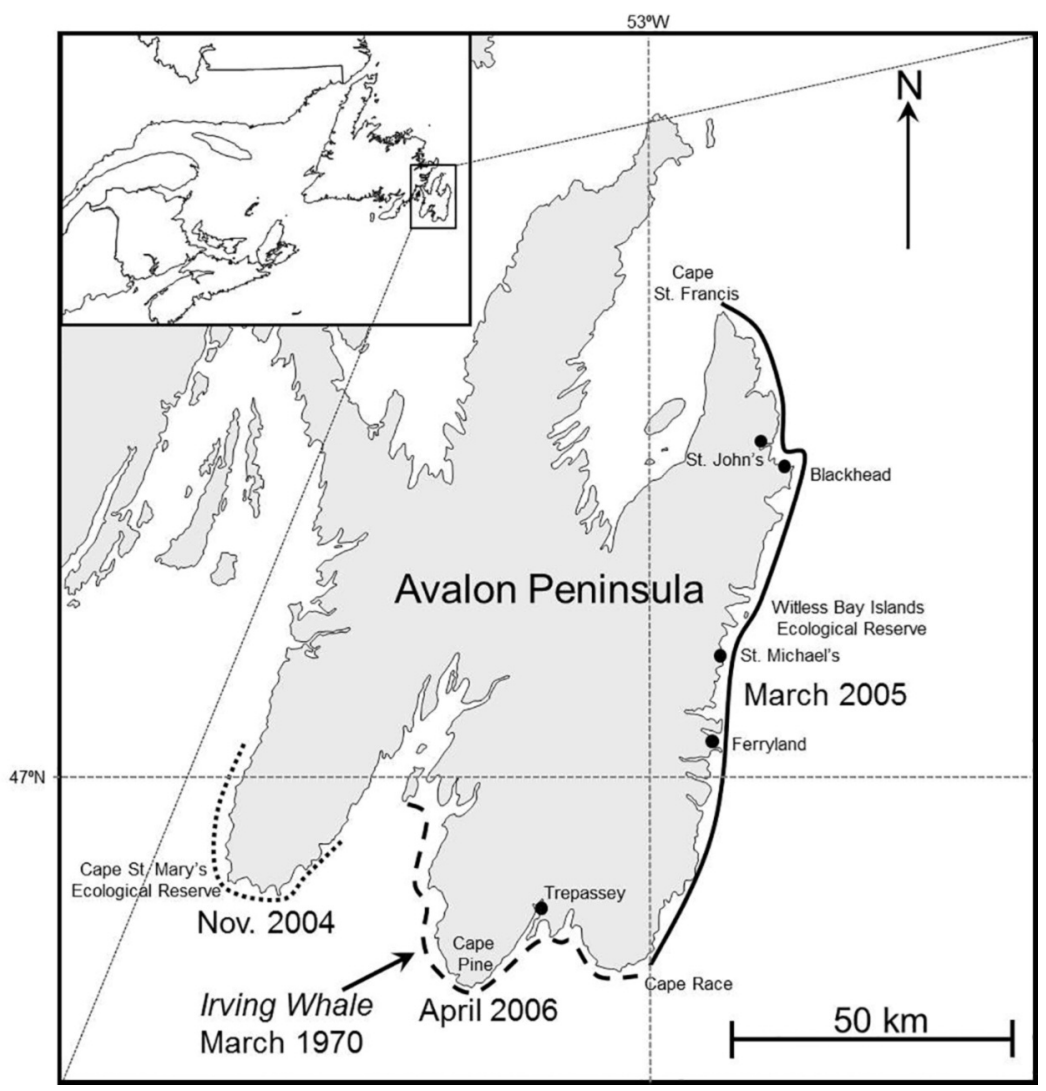

FIGURE 1. Extent of two oiling events in southeastern Newfoundland, March 2005 (solid line) and April 2006 (dashed line). The locations of two other events mentioned in the text are also shown: Irving Whale, March 1970 (arrow; Brown et al. 1973) and November 2004 (dotted line; Robertson et al. 2006).

the focus was on birds that may have been oiled. This survey was conducted from south to north at $35 \mathrm{~m}$ above sea level, and the number of eiders loafing on beaches and rocks was recorded; in some cases oiling was visibly apparent on these birds. The number and location of Bald Eagles (Haliaeetus leucocephalus [Linnaeus, 1766]) that appeared to be scavenging oiled eiders was also noted.

On 6 March 2005, a second survey was conducted specifically to count the number of eiders that appeared oiled. This survey included simultaneous air and ground counts to correct for observer bias in estimating flock sizes (see Bordage et al. 1998) and to determine whether eiders were indeed oiled. Fifteen ground count sites were identified at 4 locations: Cape St. Francis, Blackhead, St. Michael's, and Ferryland (Figure 1). On 5 March 2005, the primary helicopter surveyor (S.G.G.) visited the ground sites with each observer, who would be counting eiders the next day, to ensure that the same geographic areas were being assessed simultaneously from the air and the ground. Observers on the ground counted eiders every 30 minutes at their site. As it was apparent that eiders flushed with the arrival of the helicopter, the previous count was used. Helicopter survey protocols were similar to those used on the return portion of the 1 March survey, except a 206 LR (Bell Helicopter Trextron Canada Ltd, Mirabel, Quebec, Canada) from Universal Helicopters (Goose Bay, Newfoundland and Labrador) was used for the portion of the flight from Logy Bay (near St. John's) to Cape Bonavista $\left(48^{\circ} 42^{\prime} \mathrm{N}, 53^{\circ} 05^{\prime} \mathrm{W}\right)$ to the north. The flight ran south to north and took place from 0850 to 1430 . Survey conditions again were generally good: light winds, clear sky, and $-12^{\circ} \mathrm{C}$; however visibility was restricted by local snow squalls. The ratio of ground count to aerial count was calculated for each site where birds were present, and the mean of those ratios was used to correct the aerial counts.

From 26 February to 7 April 2005, crews searched beaches daily for oiled bird carcasses. In addition, birds (and parts) were received from the public, mostly hunters, in late February. 
We examined all carcasses received, recording the species, sex, age where possible, degree of scavenging, and degree of oiling. We measured body mass and commonly recorded morphometrics (wing, tarsus, and culmen length) of intact carcasses. For Common Eiders, we also measured aspects of the bill used in subspecific identification (Mendall 1986) and assessed visually whether the bird was borealis, dresseri Sharpe, 1871, or an intergrade between these subspecies based on bill shape and colouration (Goudie et al. 2000). Given the uncertainty of distinguishing the borealis subspecies from intergrades, the category "northern-type common eider," which included borealis and intergrades, was used (Gilliland and Robertson 2009). To determine whether oiled eiders had lost body condition before being found, we measured the body mass of $60 \mathrm{Com}-$ mon Eiders shot between December 2004 and February 2005 near Point Lance, Newfoundland (near Cape St. Mary's) to compare with the mass of oiled carcasses. Even though this sample was collected earlier in the winter than the oiled birds, they should be comparable as northern Common Eiders do not show strong seasonality in body mass dynamics during the winter (Jamieson et al. 2006).

\section{April 2006 incident}

On 9 April 2006, reports were received from the public of oiled birds, including gulls, auks, and Long-tailed Ducks (Clangula hyemalis [Linnaeus, 1758]) sighted along the southeast coast of the Avalon Peninsula, near Cape Pine and the town of Trepassey (Figure 1). Response teams were deployed to examine beaches from 10 to 18 April. On 12 April, two observers (S.G.G. and G.J.R.) conducted a shoreline survey in a 206 LR helicopter to look for oiled sea ducks, following protocols similar to those described for the March 2005 survey. Skies were clear and survey conditions were very good.

As the birds affected by this oiling event were a varied mix of coastal and pelagic species, a minimum number for each affected species was derived from a variety of sources: for waterfowl, the birds counted on shore on 12 April and any carcasses collected before that date were summed; for species not well assessed by aerial surveys, the number of dead carcasses collected, plus reliable observations of oiled birds from areas outside the beaches regularly surveyed were summed. Birds were measured as described above, but a visual assessment of the subspecific status of Common Eiders was not conducted.

\section{Results}

\section{March 2005 incident}

We estimated that on 1 March 2005, there were approximately 42000 Common Eiders along the eastern Avalon Peninsula of Newfoundland; this represented a raw count and was not corrected for observer bias. Assuming that all eiders that were hauled out on beaches and rocks were oiled, we estimated the number of oiled eiders at 1165. Major concentrations of birds were located on islands, which are relatively sparse along this coast, with most on the larger islands in the Witless Bay Islands Ecological Reserve (Figure 1). In addition to the eiders, we observed at least two oiled Long-tailed Ducks, and one dead Northern Gannet (Morus bassanus [Linnaeus, 1758]). During the 6 March 2005 helicopter survey, we counted 537 oiled eiders along the eastern Avalon Peninsula. Once again, major concentrations were found on the islands of the Witless Bay Islands Ecological Reserve, and extended further north to include Cape St. Francis (Figure 1). In addition to the eiders, we observed at least two oiled Longtailed Ducks.

We successfully conducted simultaneous air and ground counts at four locations (Table 1). The ground counts were slightly higher than the corresponding aerial counts (ratio 1.07, standard error [SE] 0.14); using this ratio to adjust for errors in the aerial counts, we estimated that 577 (SE 75) eiders may have been affected by oil on 6 March. Based on other casual observations of oiled eiders at sites that were not detected by the helicopter, we believe this is an underestimate.

TABLE 1. Simultaneous aerial and ground counts of oiled Common Eiders (Somateria mollissima) at four loafing locations, 6 March 2005, in Newfoundland.

\begin{tabular}{lcc}
\hline \hline Location (site) & Ground count & Aerial count \\
\hline Cape St. Francis & 84 & 85 \\
Blackhead & 6 & 0 \\
St. Michael's & & \\
$\quad$ Site 1 & 1 & 1 \\
Site 2 & 0 & 0 \\
Site 3 & 0 & 0 \\
Site 4 & 22 & 9 \\
Site 5 & 0 & 0 \\
Cribbies & 2 & 2 \\
Ferryland & & \\
Site 1 & 3 & 2 \\
Site 2 & 1 & 5 \\
Site 3 & 1 & 3 \\
Site 4 & 0 & 0 \\
Site 5 & 0 & 0 \\
Site 6 & 1 & 1 \\
Total & 121 & 108 \\
\hline \hline
\end{tabular}

Most of the carcasses retrieved during this incident were Common Eiders, although carcasses of another five species were also retrieved (Table 2). In addition, another four species were seen oiled: Purple Sandpiper (Calidris maritima [Brunnich, 1764]), Common Loon (Gavia immer [Brunnich, 1764]), American Herring Gull (Larus smithsonianus Coues, 1862), and Long-tailed Duck. Based on visual inspection, most eiders found were of the northern (borealis) or intermediate-northern type (males: $92 \%, n=36$; females: $92 \%, n=25)$. However, using Mendall's (1986) key, more males were classified as dresseri $(42 \%, n=36)$. 
TABLE 2. Species and ages of oiled birds collected on beaches or provided by hunters after an oil spill incident in southeastern Newfoundland, March 2005.

\begin{tabular}{|c|c|c|c|c|}
\hline & Immature & Adult & Unknown age & Total \\
\hline \multicolumn{5}{|l|}{ Common Eider (Somateria mollissima) } \\
\hline Female & 4 & 29 & 11 & 44 \\
\hline Male & 16 & 28 & 4 & 48 \\
\hline Thick-billed Murre (Uria lomvia) & & 2 & 3 & 5 \\
\hline Dovekie (Alle alle) & & 1 & & 1 \\
\hline Black Guillemot (Cepphus grylle) & 2 & & 1 & 3 \\
\hline Great Black-backed Gull (Larus marinus) & 1 & & 1 & 2 \\
\hline
\end{tabular}

Of the males, where more specific aging based on plumage was possible, $28(64 \%)$ were found to be adults, $16(36 \%)$ were sub-adults and none were juveniles. Female and male oiled eiders were $15 \%$ and $16 \%$ lighter, respectively, than eiders shot earlier the same winter (females: oiled $1445 \mathrm{~g}$, SD $133 \mathrm{~g}, n=24$; unoiled 1694 g, SD $138 \mathrm{~g}, n=32$; males: oiled $1600 \mathrm{~g}$, SD $218 \mathrm{~g}, n=33$, unoiled $1904 \mathrm{~g}$, SD $104 \mathrm{~g}, n=28$ ). Live oiled eiders were seen well into April 2005 around the eastern Avalon Peninsula, after which eiders left the area on migration, indicating that this species may survive for over a month after oiling.

\section{April 2006 incident}

Between 10 and 16 April 2006, 186 oiled carcasses of 11 species were collected on the southeastern tip of the Avalon Peninsula (Table 3, Figure 1). The most common species recovered were sea ducks (Common Eider 18.6\%; Long-tailed Ducks 12.9\%) and auks (murres 48.4\%; Black Guillemots [Cepphus grylle
(Linnaeus, 758)] 13.4\%; Dovekies and Atlantic Puffins [Fratercula arctica (Linnaeus, 1758)] 1.1\% each). During the 12 April 2006 aerial survey, 409 birds were seen on shore and assessed as oiled: these included 320 Common Eiders, 64 Long-tailed Ducks, 12 loons, 9 murres, 3 Black Guillemots, and a White-winger Scoter (Melanitta fusca [Linnaeus, 1758]). The extent of the distribution of Common Eiders presumed oiled was smaller than that seen after the 2005 event (Figure 1). Combining the aerial survey with the carcass recovery data and adding oiled birds seen outside the main area of focus, we estimate that a minimum of 574 birds of 19 species were affected by this spill (Table 4).

Among recovered Common Eiders, 21 of 22 birds were adults (95.5\%), but the sex ratio was close to even (18 females of 34 birds, $52.9 \%$ ) (Table 3). Similarly, among Long-tailed Ducks, 18 of $21(85.7 \%)$ birds were adults, but 20 of 24 birds were male (83.3\%). Based

TABLE 3. Species and ages of oiled birds recovered on beaches in southeastern Newfoundland, April 2006.

\begin{tabular}{|c|c|c|c|c|c|c|c|c|c|c|}
\hline \multirow[b]{2}{*}{ Species } & \multicolumn{3}{|c|}{ Juvenile } & \multicolumn{3}{|c|}{ Adult } & \multicolumn{3}{|c|}{ Unknown } & \multirow[b]{2}{*}{ Tota } \\
\hline & $\bar{F}$ & $\mathrm{M}$ & $\bar{U}$ & $\bar{F}$ & $\mathrm{M}$ & $\bar{U}$ & $\overline{\mathrm{F}}$ & $\mathrm{M}$ & $\bar{U}$ & \\
\hline $\begin{array}{l}\text { Common Loon } \\
\text { (Gavia immer) }\end{array}$ & & & 1 & 1 & 1 & 2 & & & 1 & 6 \\
\hline $\begin{array}{l}\text { Northern Fulmar } \\
\text { (Fulmarus glacialis) }\end{array}$ & & & & & & 1 & & & & 1 \\
\hline $\begin{array}{l}\text { Common Eider } \\
\text { (Somateria mollissima) }\end{array}$ & 1 & & & 6 & 15 & & 11 & 1 & & 34 \\
\hline $\begin{array}{l}\text { Long-tailed Duck } \\
\text { (Clangula hyemalis) }\end{array}$ & & 3 & & 3 & 15 & & 1 & 2 & & 24 \\
\hline $\begin{array}{l}\text { American Herring Gull } \\
\text { (Larus smithsonianus) }\end{array}$ & & & & & & & & & 2 & 2 \\
\hline $\begin{array}{l}\text { Common Murre } \\
\text { (Uria aalge) }\end{array}$ & & 2 & 12 & 1 & 1 & 13 & & & 4 & 33 \\
\hline $\begin{array}{l}\text { Thick-billed Murre } \\
\text { (Uria lomvia) }\end{array}$ & 1 & & 6 & 5 & 4 & 28 & & & 2 & 46 \\
\hline Murre (Uria spp.) & & & & & & & & & 11 & 11 \\
\hline Dovekie (Alle alle) & & & & & & & & & 2 & 2 \\
\hline $\begin{array}{l}\text { Black Guillemot } \\
\text { (Cepphus grylle) }\end{array}$ & 1 & 1 & & & 1 & 7 & & & 15 & 25 \\
\hline $\begin{array}{l}\text { Atlantic Puffin } \\
\text { (Fratercula arctica) }\end{array}$ & & & & & & & & & 2 & 2 \\
\hline
\end{tabular}

Note: $\mathrm{F}=$ female, $\mathrm{M}=$ male, $\mathrm{U}=$ unknown. 
TABLE 4. Minimum numbers of birds by species affected by an oiling incident in southeastern Newfoundland, April 2006. Numbers are totals of birds seen ashore during aerial surveys (ducks), found before the aerial survey, found after the survey and not counted during the aerial survey (auks), and oiled birds reported outside the survey area.

\begin{tabular}{lc}
\hline \hline Species & $\begin{array}{c}\text { Minimum } \\
\text { number oiled }\end{array}$ \\
\hline Common Eider (Somateria mollissima) & 337 \\
Murre (Uria spp.) & 98 \\
Long-tailed Duck (Clangula hyemalis) & 66 \\
Black Guillemot (Cepphus grylle) & 29 \\
Loon (Gavia spp.) & 23 \\
American Herring Gull (Larus smithsonianus) & 7 \\
Razorbill (Alca torda) & 2 \\
Dovekie (Alle alle) & 2 \\
Great Black-backed Gull (Larus marinus) & 2 \\
Red-necked Grebe (Podiceps grisegena) & 1 \\
Northern Fulmar (Fulmarus glacialis) & 1 \\
King Eider (Somateria spectabilis) & 1 \\
White-winged Scoter (Melanitta fusca) & 1 \\
Purple Sandpiper (Calidris maritima) & 1 \\
Atlantic Puffin (Fratercula arctica) & 1 \\
Ring-billed Gull (Larus delawarensis) & 1 \\
Glaucous Gull (Larus hyperboreus) & 1 \\
Total & 574 \\
\hline \hline
\end{tabular}

*Includes Common (Gavia immer) and Red-throated Loon (G. stellata).

on Mendall's (1986) subspecific key, three of the 12 female Common Eiders measured were classified as borealis, eight as intergrades, and one as dresseri. Of the 14 males, six were classified as borealis, four as intergrades, and four as dresseri. All five of the birds classified as dresseri had a total culmen length within $1 \mathrm{~mm}$ of the range for the intergrade category, and we suspect that these 5 birds were borealis-dresseri intergrades. As in the March 2005 incident, the mass of oiled eiders was low: mean for females $1359 \mathrm{~g}$ (SD $136 \mathrm{~g}$, range 1145-1479 $\mathrm{g}, n=5$ ); mean for males $1585 \mathrm{~g}$ (SD $153 \mathrm{~g}$, range $1430-1864 \mathrm{~g}, n=6$ ). The mass of oiled male Long-tailed Ducks was $527 \mathrm{~g}$ (SD $93 \mathrm{~g}$, range 434-608 g, $n=4$ ) and the one female weighed $675 \mathrm{~g}$.

Of the murres that could be identified to species, $41.8 \%$ (33 of 79) were Common Murres (Uria aalge [Pontoppidan, 1763]) and 58.2\% were Thick-billed Murres (U. lomvia [Linnaeus, 1758]). The age ratios were different for the two murre species: $51.7 \%$ of Common Murres were older than one year, while $84.1 \%$ of Thick-billed Murres were older than one year. The mean body mass of Thick-billed Murres was $711 \mathrm{~g}$ (SD $81 \mathrm{~g}$, range 596-822 g, $n=8$ ) and that of Common Murres was $804 \mathrm{~g}$ (SD $37 \mathrm{~g}$, range 774$844 \mathrm{~g}, n=4)$. These masses are $26.0 \%$ and $21.0 \%$ lighter, respectively, than wintering murres collected in Newfoundland in the 2000s (Thick-billed Murres 958 g, $n=113$, McFarlane Tranquilla et al. [2010]; Common Murres: $1018 \mathrm{~g}, n=63$ ). A sufficient sample was available for measurement of adult Thick-billed Murres: wing length $215 \mathrm{~mm}$ (SD $6 \mathrm{~mm}$, range 206$231 \mathrm{~mm}, n=24$ ); culmen $33.9 \mathrm{~mm}$ (SD $2.2 \mathrm{~mm}$, range $30.4-37.7, n=18)$.

\section{Discussion}

The Avalon Peninsula harbours important concentrations of wintering Common Eiders, especially later in the winter, as birds move south in advance of sea ice formed to the north (Goudie et al. 2000) and in early spring when they begin their northern migration. This was certainly the case in March 2005, when we counted 42000 eiders along the eastern stretch of the peninsula. Sea ice was notably heavy on the northeastern coast of Newfoundland in February 2005, forcing eiders into small open water leads where they were highly vulnerable to hunting or south into more open water. Therefore, large numbers of eiders were expected around southeastern Newfoundland during this winter.

Based on behaviour that was also noted by Brown et al. (1973) by eiders involved in the Irving Whale incident, we assumed that at least 1165 eiders were oiled. Eiders in unoiled areas flushed well in advance of the aircraft, but birds suspected to be oiled only flushed on close approach or did not flush at all, as was the case among heavily oiled birds hiding in vegetation adjacent to the shoreline (Brown et al. 1973). Therefore, the behaviour of oiled eiders appears to be consistent: they remain close to or on shore and do not respond to an approaching aircraft unless it is very close. On this basis, we are reasonably confident in assuming that all eiders found loafing on islands were oiled, and this likely represents a minimum number. Based on our count of 1165 oiled birds on 1 March 2005, plus oiled eiders shot and reported by hunters, at least 1400 eiders were assumed to be oiled, and this number could easily be larger. Fewer (337) oiled Common Eiders were recorded after the April 2006 incident, but again this represents a minimum.

We detected several large aggregations of loafing eiders on the first flight in 2005 ( 1 March): $55 \%$ of all the eiders encountered during this survey were located at five sites with $75-300$ birds each, while only $15 \%$ occurred in groups of less than 10 birds. We believed that the greatest source of error was our inability to estimate accurately the number of eiders affected from the air, and we followed this survey with a second flight on 6 March 2005 combining independent aerial and ground counts to correct for observer biases in flock estimation (see Bordage et al. 1998). However, by the second survey, all but two of the large aggregations had dissipated (the two largest counts of remaining birds were 65 and 85) and the challenge was detecting individuals or small groups of eiders that were distributed across more than $200 \mathrm{~km}$ of coastline. In the future, we recommend that aerial assessments be conducted as soon after an incident as possible to count affected birds 
when they occur in large aggregations that are easily detected. Ground counts or photographs should be used to correct observer biases in flock estimation. If the birds are widely distributed in small groups, we suggest using double-observer approaches (see Nichols et al. 2000) to allow more precise estimates of the number of birds affected.

The reduction in the number of oiled eiders recorded between the 1 March and 6 March 2005 surveys is noteworthy and may have resulted from a number of causes. The first possibility is that birds perished in the interim, although large numbers of carcasses were not noted at these sites during the 6 March survey or during beach surveys. Eiders appeared to show more "normal" behaviour at the time of the 6 March survey; thus, more lightly oiled birds may have been in the water foraging or loafing and would not have been assessed as oiled. If this is the case, assessments of oiled eiders should take place as soon as possible after an incident and before lightly oiled birds adjust and establish a somewhat normal behavioural routine. Clearly more work is needed to understand the behaviour of oiled birds in the wild so that surveys that best reflect the numbers of birds oiled during an event can be implemented.

Among oiled birds, adults predominated in both incidents, especially the April 2006 event. This was also noted by Brown et al. (1973) in the Irving Whale spill, which occurred in March 1970 in the same general area as the April 2006 spill. Sex ratios were close to one, however, which differs from the male-biased ratio noted by Brown et al. (1973). Most Common Eiders found in both incidents were either members of the northern, or borealis, subspecies, or presumed intergrades between the northern and American, dresseri, subspecies. In fact, most individuals were classified as borealis-dresseri intergrades, which are found breeding in central Labrador (Mendall 1986). Pure borealis Common Eiders that breed in the eastern Canadian Arctic winter mainly in Greenland, although about a quarter of the population winters off Newfoundland and in the Gulf of St. Lawrence (Mosbech et al. 2006). The Common Eider population breeding in Labrador has been growing (Chaulk et al. 2005) and is assumed to overwinter exclusively in eastern Canada. In identifying subspecies, we found some discrepancies between visual inspection of eiders and the use of bill morphology to key eiders to subspecies (Mendall 1986). When developing the key, Mendall did not have a large selection of intergrades, especially males, to include in the analysis. Some more work on determining subspecies of Common Eiders, especially in hybrid zones such as Labrador, is still needed.

Common Eiders are popular game birds in Newfoundland and Labrador and Greenland, and concerns have been raised about the harvest levels, which, according to Gilliland et al. (2009), ranged from 68000 to 83000 northern eiders annually in the two countries.
This assessment of harvest levels suggested that if 6500 female borealis are taken annually in Canada, the harvest should be sustainable. The 1400 eiders assumed to be oiled in the March 2005 event, of which half were female, would add at least another $11 \%$ to the overall winter take, possibly pushing the population into decline for that season (assuming oiling was in addition to natural and hunting mortality). The fact that most oiled eiders were adults — unlike hunted birds, which are largely juveniles (Gilliland and Robertson 2009) - only exacerbates the pressure this event placed on the population.

Recovered carcasses of Common Eiders were somewhat lighter than normal wintering birds, but they were not as emaciated as murres, and living oiled eiders were observed for over a month after the initial oiling event. Therefore, unlike murres and other auks, Common Eiders appear to be able to sustain some level of oiling and survive. Eiders are inshore feeders, foraging in shallow intertidal and subtidal waters. When oiled, eiders, like the auks, come to shore in large numbers, presumably to avoid frigid waters and the risk of hypothermia resulting from oiled plumage. However, food for eiders is readily available close to shore, and eiders can continue to dive, feed, and return quickly to shore. In contrast, auks that come to shore are far removed from their food source and eventually succumb to starvation. Even if oiled birds are unable to forage, Common Eiders, at least females, are adapted to withstand severe loss of body mass (up to $40 \%$ ) and condition while they incubate their clutch (Parker and Holm 1990). What is not known is the long-term viability of the eiders that were lightly oiled. Even if they survived, future reproductive attempts by these birds may be compromised, as minute levels of hydrocarbons have been shown to severely disrupt or inhibit reproduction (Leighton 1993; Stubblefield et al. 1995), and lingering long-term physiological impairment has been shown in birds that were exposed to sub-lethal doses of hydrocarbons (Alonso-Alvarez et al. 2007a,b).

The species composition of murres found in the April 2006 incident was similar in some respects, but also differed from those seen in the November 2004 incident (Robertson et al. 2006). Common Murres made up a larger proportion of the murres recovered in April 2006, reflecting their prevalence along the south coast of Newfoundland, especially later in the winter season. In spite of the proximity of Common Murre breeding colonies to the affected area (both Cape St. Mary's and Witless Bay Island Ecological Reserves are less than $100 \mathrm{~km}$ away), the majority of recovered Common Murres were juveniles. On the other hand, most Thick-billed Murre carcasses were adults, in a proportion comparable to what would be expected in the population at large (Wiese et al. 2004). Body masses of both species were lower than expected for wintering birds. However, the mass of Thick-billed Murres was not quite as low as that of starved birds found in 
the "seabird wrecks" of 2007 and 2009 when beached dead birds were found to weigh $622 \mathrm{~g}$ and $639 \mathrm{~g}$ on average, respectively (McFarlane Tranquilla et al. 2010), indicating that oiled birds had some remaining body reserves and hypothermia, toxicity of oil, or both, contributes to the death of oiled murres. Wing and culmen measurements were typical of birds breeding in the Northwest Atlantic and similar to those involved in other oiling events (Brown et al. 1973; Robertson et al. 2006). Of note was the lack of Dovekies, which are a common victim of oiling in Newfoundland waters (Wiese and Ryan 2003; Robertson et al. 2006). Possibly Dovekies had begun to move north on migration by the time of the incident in April 2006.

The April 2006 event was noteworthy in terms of the wide variety of avifauna affected: no less than 19 species, including sea ducks, alcids, loons, gulls, and even a sandpiper and a tubenose. This impact is related to both the timing and location of the event. Unlike many parts of southeastern Newfoundland, the southern tip of the Avalon Peninsula has extensive beach habitat in addition to the rockier cliff habitat surrounding most of the peninsula. This habitat diversity leads to a broader avian community. In addition, in mid-April, many species would be congregating for the spring migration, and others would have begun migration. The spill was early enough that the main wintering aggregations of both eiders and murres had not yet left the area, as most of the eiders were of the northern types and Thickbilled Murres dominated among the recovered murre carcasses (both of these species breed north of Newfoundland). Both inshore (ducks, loons) and offshore species (auks, fulmars) were affected, suggesting that this slick likely started somewhere out from shore and was blown inshore.

Between the April 2006 oiling incident and April 2014 , there have been no notable (i.e., affecting $>10$ birds) inshore oiled bird events in Newfoundland from unknown sources, although significant numbers of oiled birds have been found associated with the $M / V$ Manolis $L$ wreck on the northeast coast of Newfoundland. Regular long-term beached bird surveys in southeastern Newfoundland are also beginning to show a reduction in the number of oiled birds coming to shore (Wilhelm et al. 2009). In 2005, federal legislation was passed in Canada directed at reducing the chronic shipsource oil pollution problem (Elmslie 2006); concomitantly, additional surveillance and enforcement and education programs were put in place to target this issue. Although continued monitoring is warranted, the indications are that a reduction in chronic ship-source oiling, at least in inshore waters off southeastern Newfoundland, is occurring.

\section{Acknowledgements}

We thank the many agencies and individuals who assisted in the response to these oiling events. In addition to collating reports and collecting carcasses, the
Canadian Coast Guard provided helicopter support for the various surveys. Graham Thomas, the Government of Canada's Environmental Emergencies Programs, and members of the Atlantic Regional Environmental Emergencies Team provided key oversight of these responses. Sabina Wilhelm, François Bolduc, and an anonymous reviewer provided helpful comments on an earlier draft of this manuscript.

\section{Literature Cited}

Alonso-Alvarez, C., I. Munilla, M. López-Alonso, and A. Velando. 2007a. Sublethal toxicity of the Prestige oil spill on yellow-legged gulls. Environment International 33: 773781.

Alonso-Alvarez, C., C. Pérez, and A. Velando. 2007b. Effects of acute exposure to heavy fuel oil from the Prestige spill on a seabird. Aquatic Toxicology 84: 103-110.

Bordage, D., N. Plante, A. Bourget, and S. Paradis. 1998. Use of ratio estimators to estimate the size of common eider populations in winter. Journal of Wildlife Management 62: 185-192.

Brown, R. G. B., D. I. Gillespie, A. R. Lock, P. A. Pearce, and G. H. Watson. 1973. Bird mortality from oil slicks off eastern Canada, February-April 1970. Canadian FieldNaturalist 87: 225-234.

Chaulk, K. G., G. J. Robertson, B. T. Collins, W. A. Montevecchi, and B. Turner. 2005. Evidence of recent population increases in common eiders breeding in Labrador. Journal of Wildlife Management 69: 805-809.

EImslie, K. 2006. From sea to senate: the outcome of Bill C-15 in the fight to save 300,000 seabirds. Pages 58-60 in The Effects of Oil on Wildlife: Proceedings of the Eighth International Conference. Tri-State Bird Rescue and Research Inc., Newark, Delaware, USA.

Gilliland, S. G., and G. J. Robertson. 2009. Composition of eiders harvested in Newfoundland. Northeastern Naturalist 16: 501-518.

Gilliland, S. G., H. G. Gilchrist, R. F. Rockwell, G. J. Robertson, J.-P. L. Savard, F. Merkel, and A. Mosbech. 2009. Evaluating the sustainability of harvest among northern common eiders Somateria mollissima borealis in Greenland and Canada. Wildlife Biology 15: 24-36.

Goudie, R. I., G. J. Robertson, and A. Reed. 2000. Common Eider (Somateria mollissima). Number 546 in The Birds of North America, edited by A. Poole and F. Gill. Academy of Natural Sciences of Philadelphia and the American Ornithologists' Union, Philadelphia, Pennsylvania, USA.

Jamieson, S. E., H. G. Gilchrist, F. R. Merkel, A. W. Diamond, and K. Falk. 2006. Endogenous reserve dynamics of northern common eiders wintering in Greenland. Polar Biology 29: 585-594.

Leighton, F. A. 1993. The toxicity of petroleum to birds. Environmental Reviews 1: 92-103.

Lock, A. R., R. G. B. Brown, and S. H. Gerriets. 1994. A gazetteer of marine birds in Atlantic Canada. Environment Canada, Canadian Wildlife Service, Atlantic Region, Dartmouth, Nova Scotia, Canada.

McFarlane Tranquilla, L., A. Hedd, C. Burke, W. A. Montevecchi, P. M. Regular, G. J. Robertson, L. A. Stapleton, S. I. Wilhelm, D. A. Fifield, and A. D. Buren. 2010. High Arctic sea ice conditions influence marine birds wintering in Low Arctic regions. Estuarine, Coastal and Shelf Science 89: 97-106. 
Mendall, H. L. 1986. Identification of eastern races of the Common Eider. Pages 82-88 in Eider Ducks in Canada. Edited by A. Reed. Canadian Wildlife Service Report Series 47. Environment Canada, Ottawa, Ontario, Canada. 177 pages.

Mosbech, A., G. Gilchrist, F. Merkel, C. Sonne, A. Flagstad, and H. Nygaard. 2006. Year-round movements of Common Eiders breeding in the Arctic Canada and West Greenland followed by satellite telemetry. Ardea 94: 651665.

Nichols, J. D., J. E. Hines, J. R. Sauer, F. W. Fallon, J. E. Fallon, and P. J. Heglund. 2000. A double-observer approach for estimating detection probability and abundance from point counts. Auk 117: 393-408.

Parker, H., and H. Holm. 1990. Patterns of nutrient and energy-expenditure in female common eiders nesting in the high Arctic. Auk 107: 660-668.

Robertson, G. J., P. C. Ryan, J. Dussureault, B. C. Turner, S. I. Wilhelm, and K. Power. 2006. Composition of beached marine birds from an oiling event in southeastern Newfoundland, November 2004. Marine Ornithology 34: 141-146.

Stubblefield, W. A., G. A. Hancock, H. H. Prince, and R. K. Ringer. 1995. Effects of naturally weathered Exxon-
Valdez crude oil on mallard reproduction. Environmental Toxicology and Chemistry 14: 1951-1960.

Wendt, J. S., and E. Silieff. 1986. The kill of eiders and other seaducks by hunters in eastern Canada. Pages 147-154 in Eider Ducks in Canada. Edited by A. Reed. Canadian Wildlife Service Report Series 47. Environment Canada, Ottawa, Ontario, Canada. 177 pages.

Wiese. F. K., and P. C. Ryan. 2003. The extent of chronic marine oil pollution in southeastern Newfoundland waters assessed through beached bird surveys 1984-1999. Marine Pollution Bulletin 46: 1090-1101.

Wiese, F. K., G. J. Robertson, and A. J. Gaston. 2004. Impacts of chronic marine oil pollution and the murre hunt in Newfoundland on thick-billed murre Uria lomvia populations in the eastern Canadian Arctic. Biological Conservation 116: 205-216.

Wilhelm, S. I., G. J. Robertson, P. C. Ryan, S. Tobin, and R. D. Elliot. 2009. Re-evaluating the use of beached bird oiling rates to assess long-term trends in chronic oil pollution. Marine Pollution Bulletin 58: 249-255.

Received 23 January 2014

Accepted 10 March 2014 